\title{
The Role of Information and Communication Technology in Sustainable Development Goals in Africa: A Review
}

\author{
Article by Barnabas Mwansa \\ PhD, Business and Management, Texila American University, Guyana \\ E-mail: barnabas.mwansa@gmail.com
}

\begin{abstract}
Technology plays a critical role in transforming societies and economies through enhancing efficiency, connectivity and access to resources and services. Sustainable development goals require harnessing technological innovation through utilization of information and communication technology. However, the challenge remains of how Africa can harness technologies to achieve sustainable development goals. This paper is a review of journal articles on the role of information and communication technology in sustainable development goals in the African context; it discusses challenges and opportunities in the light of youth employment, financial inclusion and health care. It identifies existing appropriate forms of technology that could enhance sustainable development goals and demonstrates the role of information and communication technology in achieving sustainable development goals in Africa. The paper concludes that Africa will need to vigorously utilize appropriate technology to achieve sustainable development goals.
\end{abstract}

Keywords: Technology, Sustainable Development Goals, Youth Employment, financial inclusion, health Care, ICT in Africa.

\section{Introduction}

There is a great recognition that utilization of information and communication technology is at the heart of achieving sustainable development goals. "Technology plays a critical role in transforming societies and economies through enhancing efficiency, connectivity and access to resources and services" (Al-Jayyousi, 2017). Sustainable development goals (SDGs) require harnessing information and communication technology. However, the challenge remains of how Africa can harness information and communication technologies to achieve sustainable development goals.

While, Africa has made great strides in adopting information and technology communications in its quest to advance development, challenges and opportunities exist for Africa to fully harness appropriate technology to address youth employment, financial inclusion and health care. DESA (2008) observe that Africa still lags behind in its pace of [technological] innovation. Recognizing the role of information and communication technology in achieving sustainable development goals in Africa, this paper attempts to review existing articles on the role of information and communication technology in sustainable development goals in Africa.

The paper does not analyze the impact of sustainable development goals, but rather endeavor to highlight the role of information and communication technology in achieving SDGs. The paper, firstly, discusses the method used in examining the role of technology in sustainable development goals. It then, presents definition and concept of ICTs and its link to sustainable development goals.

In details, the paper gives an overview of SDGs and discusses the role and impact of information communication technology in sustainable development goals in general. Specifically, the paper discusses utilization of ICT in Africa to achieve SDGs and highlights challenges and opportunities in the light of youth employment, financial inclusion and health care in the African context. 
DOI: $10.21522 / \mathrm{TIJAR} .2014 .04 .02 . A r t 008$

ISSN: $2520-3088$

\section{Method}

This paper conducted a review of articles published on the role of technology in sustainable development by undertaking a search of keywords in scholarly databases and internet sources. Article reviews were undertaken in three specific areas: the role of information and communication technology in sustainable development in Africa and developing countries, how can Africa harness technology to achieve sustainable development goals, debate about information and communication technology in youth employment, financial inclusion, health care and agriculture.

The paper focused its review of articles around appropriate technologies for Africa required to contribute to sustainable development goals. In addition, the paper used published case studies on the role technology in sustainable development based on NGOs' reports and international development agencies. It should be noted that while the review aims to summarize the relevant literature on the topics outlined above, it does not provide an exhaustive representation of the literature on each topic. Rather, prominent, widely cited and insightful literature was selected to inform the wider research.

The rationale for the selection of articles for inclusion in the review was those which intersected the issues of the role of information and communication technology to development in an African context. Articles related to concepts and definitions were limited to those with multiple citations and regularly noted as prominent pieces within this field. Articles which covered similar narratives, lines of argument have been included, with each article aiming to add new insight and value to the review and findings.

\section{Definition and concept}

\section{Information and communication technology (ICTs)}

Arug and Chigozi (2016) cited Hawkridge (1983) in defining 'ICTs as a generic term referring to technologies that are used for collecting, storing, editing and passing on (communicating) information in various forms. French defines information and communication technology as "a broad based technology (including its methods, management and application) that supports the creation, storage, manipulation and communication of information" (French, 1996). OECD refers to information and communication technologies as a full range of electronic technologies and techniques used to manage information and knowledge (OECD, 2012).

ICTs are regarded as information-handling tools and they include a diverse set of goods, applications and services that are used to produce, store, process, distribute and exchange information (UNDP, 2003). Accordingly, these are part and parcel of the "old" ICTs of radio, television and telephone, and the "new" ICTs of computers, satellite, mobile phones and wireless technology and the Internet (United Nations ICT Task Force, 2003). United Nations ICT Task Force argue that these different tools are now able to work together, and combine to form our "networked world" - a massive infrastructure of interconnected telephone services, standardized computing hardware, and television, which reaches into every corner of the globe (United Nations ICT Task Force, 2003). ICT therefore covers the cabling infrastructure e.g. fiber optic cables, which carry voice, data and video communications (Mohammed and Sadiq, 2015).

This paper considers ICTs as platform to exchange data, information, knowledge and tools to implement applications (e.g. e-commerce, e-schools, e-health etc.). It is important to note that recent developments of technologies, particularly, reduction in prices, greater availability of networks and a more user-friendly approach to technologies are strengthening the role of ICTs (United Nations ICT Task Force, 2003).

\section{The role and impact of ICT and sustainable development goals}

Why are ICTs essential for the achievement of the SDGs? What are the main opportunities of ICTs to accelerate progress and maximizing the transformational change needed, as well as the challenges linked to access and connectivity for all?

In September, 2015, leaders from all over the world gathered in New York to agree on the Sustainable Development Goals (SDGs). There are 17 goals aiming to end poverty, extreme hunger, ensure quality 
education for everyone, improve healthcare, end gender inequality, protect, restore and promote sustainable use of ecosystems and to improve social and economic development, and end inequality (http://www.undp.org). According to Sachs (2014) these SDGs offer an ambitious path to end poverty, fight inequality, and tackle climate change and he state that they are wide-ranging, but have one thing in common: all rely on the enabling power of ICT.

Hoffman and Girvan (1990) note that evidence by developments from other countries that ICT as a sector can contribute immensely to the sustainable development goals. Adamali and Safdar note that ICTs can help build on synergies among the goals, realize possible multiple benefits as well as avoid barriers and conflicts on the challenging road toward SDGs (Adamali and Safdar, 2006).

ICT and SDGs report emphasize that "ICT has immense potential to speed up and scale-or increase the rate of diffusion of - a very wide range of cutting-edge technologies, applications and platforms across the economy, helping low-income countries to leapfrog to achieve key development milestones while contributing to a growth economy. Significantly, it can also dramatically reduce the costs of service delivery". The report further point out that ICT will be key in accelerating achievement of sustainable development goals in Africa in the following five ways;

1. Accelerated upscaling of critical services in health, education, financial services, smart agriculture, and low-carbon energy systems.

2. Reduced deployment costs addressing urban and rural realities.

3. Enhanced public awareness and engagement.

4. Innovation, connectivity, productivity and efficiency across many sectors.

5. Faster upgrading in the quality of services and jobs

According to Bello (2014) ICTs provide an opportunity for nations to address the digital divide and reduce poverty while registering economic growth. Bello further point out that developed and some developing nations have seen the emergence of a vibrant ICT sector that significantly contributes towards national gross domestic product (GDP) (Bello, 2014). According to Crede \& Mansell (1998), ICTs are crucially important for sustainable development in developing countries and Africa in particular.

ICT4D Report (2012) point out that ICT is, and will continue to be, a catalyst in advancing sustainable development goal. The report argues that new information and communication technologies overcome the barriers of distance and time, and significantly improve the accessibility of information and knowledge (ICT4D Report, 2012). As a result, the sharing of information and knowledge quickly and effectively becomes feasible and acts as a key element in achieving sustainable development goal (Farid, 2015).

According to Harindranath (2007) the way ICT is conceptualized makes it meaningful for any developmental goal. Afta and Ismail (2015) argue that ICT can create new jobs and opportunities, improve access to finance, improve health outcomes and agriculture performance in developing countries.

\section{Africa's utilization of ICTs is key to the success of the SDGs}

Many African countries are adopting information and technology communications to achieve SDGs. However, diffusion of ICT into Africa is at a snail's speed, such that the gap between the information-rich developed countries and Africa continues to increase every day (Baro, 2011). Consequently most African countries have not been able to reap the abundant benefits of the global information society and the information economy in areas such as education, health, commerce, agriculture and rural development (Mutula, 2004).

This figure indicates the most important indicators about ICT in Africa at the period $2005-2015$. 
DOI: $10.21522 / \mathrm{TIJAR} .2014 .04 .02 . A r t 008$

ISSN: $2520-3088$

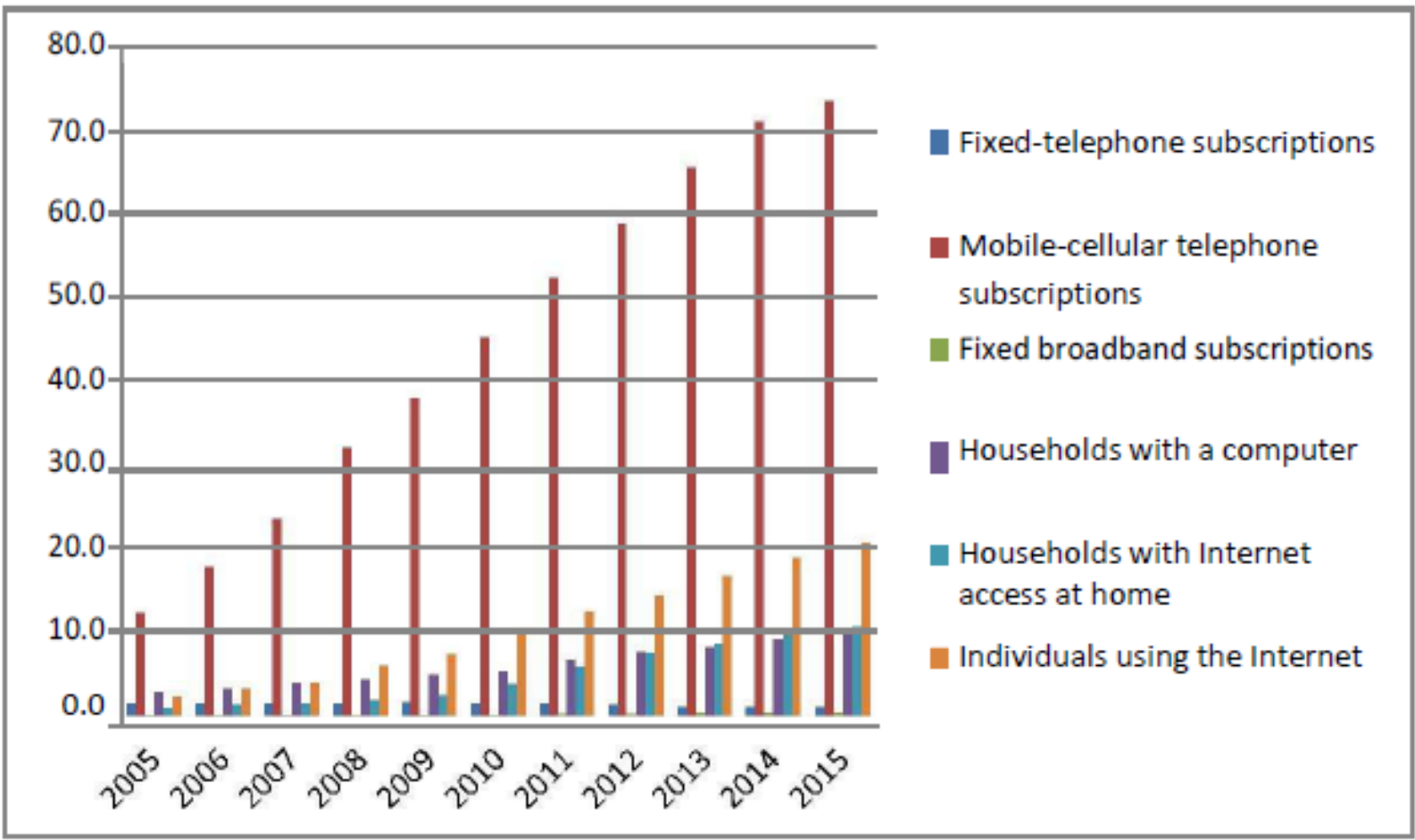

Figure 1. ICT indicators in africa

\section{Information and communication technology for youth employment in africa}

ICT offer Africa an opportunity to address the challenge of youth unemployment (Ebaidalla 2014). According to the Africa Economic Outlook (2012), Africa has the youngest population in the world, with almost 200 million people aged between 15 and 24. These young people will be in need of employment. The Africa Development Bank (2016) acknowledges that youth unemployment and underemployment constitute central challenges to Africa's sustainable development goals.

The Africa Development Bank further state that if "youth unemployment rates remain unchanged in Africa, nearly $50 \%$ of youth - excluding students - will be unemployed, discouraged, or economically inactive by 2025" (AfDB,2016). The Bank argues that the "likely consequences of these include increased poverty, social and economic exclusion, migration out of the continent, and increased risk of political tensions" (AfDB, 2016). Therefore youth employment will be critical to the achievement of SDGs goal 8 which relates to promote inclusive and sustainable economic growth, employment and decent work for all.

Ukomm and Okeagu (2015) point out that ICT will play a critical role in creating employment opportunities, empowerment and development. According to Ukomm and Okeagu (2015) the role of ICT in facilitating job creation for the youths, especially in Africa cannot be over emphasized. HAFIZ et al (2013) argue that the youths are often the leading innovators in the use and spread of ICT. HAFIZ et al (2013) further point out that the youth adapt quickly and are adventurous for new knowledge and therefore if provided with opportunities, they can translate it into livelihood ventures.

In his paper Muhammad (2015) indicates that the ICT sector was boosting the federal government effort in job creation on an average of about 12 million jobs from 2012 to date which is a significant improvement against the 2.5 million jobs the sector created" between" 2002 - 2012. According to Muhammad (2015) the World Bank in line with its investment policy has expressed its readiness in providing 2 million dollar investment on facilities to promote growth and employment projects on ICT in Nigeria in the year 2014.

ITU point that access to information means better access to capital, markets and job opportunities 
and training, for, example The World Bank state that ICTs connect youth to jobs. Online employment marketplaces are helping an estimated 12 million people worldwide find work by connecting them with employers globally (World Bank, 2007). The World Bank further indicates that Babajob in India, Duma and M-Kazi in Kenya, and Souktel in the Middle East and North Africa are examples of job search services using internet-based and mobile tools (ibid).

Michael and Samson (2014) studies indicate that "ICT era has created various types of jobs from chief information officer in big enterprises or government agencies to the computer shop operators since early 90's. According to Michael and Samson (2014) vendors of hand held phones and their accessories are common sight in every community. They argue that there are various types of ICT based businesses such as document processing centres, cybercafé, computer training centres, computer services and repairs, hand set services and repairs, internet, programming, cable and satellite TV installations, etc. with very little take off funds" (ibid).

In his view Christine zhen- Wei Qiang (2009) stated that "The mobile platform is emerging as the single most powerful way to extend economic opportunities and key services to millions of people". He further maintained that, investment in telecom services in African region between the years 20002007 reached $\$ 20$ billion and number of mobile subscribers increased from 2 million in 2000 to over 150 million in 2007 (Christine zhen- Wei Qiang, 2009). .

Mohammed and Sadiq (2016) argue that 'interconnectedness and collaboration; allowing smaller, entrepreneurial companies to compete in global markets; reducing the cost of entry for new entrepreneurs; facilitating research diversification and interdisciplinary approaches; enhancing the ability of entrepreneurs to develop new business models, products, services, and processes; shortening product development cycles; providing new tools to create, organize, store, and transmit information; and facilitating faster access to regional and international markets".

However, Mohammed and Sadiq (2016) note that "while access to technology and associated electronic content has significantly changed the lives of many young people in developed countries; this is not always the case for those in Africa". According to Michael and Samson (2014) access to ICTs such as computers, mobile phones and the Internet, especially broadband, remains a challenge for youth in Africa.

\section{Information and communication technology for financial inclusion in africa}

Helmore et al (2009) argue that beginning 1970s, financial inclusion swept through Asia and Latin America, helping countless millions of poor people get the economic boost they needed to start small businesses and work their way out of poverty. Sreedevi (2011) notes that poverty can now, in part, be redefined as a lack of access to reliable, affordable financial services that enables people to build economic security and improve their lives. Helmore et al (2009) point out that while there are more than 300 million economically active individuals in sub-Saharan Africa, only about 20 million of them - less than 10 percent - have access to any kind of formal financial services.

Helmore et al (2009) assert that if "African countries are to achieve sustainable development goals more quickly, the poor in Africa - like people everywhere - must have access to an array of flexible, cost-effective financial products and services targeted to their needs, including savings, credit and insurance". Jonathan (2008) argues that financial inclusion has the potential to improve the standards of life of the poor and the disadvantaged. According to Beck et al (2007) financial services permit individuals and households to manage the risk and uncertainties, to save on better terms, to invest in a business venture or property, or to cope with unforeseen expenses.

Boriana (2015) point out that the increasing use of mobile phones in Africa has contributed to the emergence of branchless banking services, thereby improving financial inclusion. Helmore et al (2009) .notes that mobile telephone subscriptions allow expansion and access to financial services to previously underserved groups in African countries.

Boriana (2015) argue that this increased access to financial services for underserved people helps 
narrow the financial infrastructure gap, where the costs of distance and time are very high for formal banking services. Therefore ICT and mobile phone in particular improve access to credit and deposit facilities, allow more efficient allocation of credit, facilitate financial transfers, and boost financial inclusion (Helmore et al (2009).

\section{Information and communication technology for health in africa}

The World Health Organization state that health is an important facet of sustainable development goals and has potentially to contribute to attainment of SDGs. The World Health Organization (WHO) has emphasized a need to improve health care services particularly in Africa (WHO 2014) .argue that "African countries will not develop economically and socially without substantial improvements in the health of their people".

Istepanian and Lacal (2003) state that the health-care interventions - treatments, diagnostic and preventive methods - that are needed in Africa are known. The World Health Organization point that the challenge for Africa is to deliver these to the people who need them and the best way to do this is to establish well-functioning health systems" (WHO 2014, p. xiii). According to Lucas (2008) ICT can be used to transform the health paradigm by shifting the provider-patient configuration. This typically can involve extending health care services to underserved areas by use of electronic or telecommunication means (Telemedicine) such as video chat, or health telephone hotlines (Mimbi and Bankole, 2015).

Nkqubela et al (2010) argue that ICTs enable online communication about medical issues and diagnosis of complicated diseases by linking medical practitioners who are separated geographically. They have the potential to change the delivery of healthcare services and patient care, as well as the management of healthcare systems.

\section{Discussion and conclusions}

This paper therefore assumes that ICT presents wide ranging opportunities especially for Africa to attain sustainable development goals. The paper has argued that information technology facilitates fast, cheap, equitable, and resource-efficient access to information. ICTs are important in Africa for several key reasons. First, technology can be used through commerce to generate money and capital income. Secondly, updated ICTs improve the quality of life of through creating employment opportunities, improve access to financial inclusion for the poor and support health care services. Lastly, ICT allows for easier communication, for example, through computers and production of goods using new machinery. The paper concludes that the trend of development in ICT has immensely contributed to providing job opportunities for young people who are rooming the streets due to lack of employment in Africa.

The adoption of ICT requires a business environment encouraging open competition, trust and security, interoperability and standardization, and financial resources for ICT. This requires the implementation of sustainable measures to improve access to the internet and telecommunications infrastructure and increase ICT literacy, as well as development of local internet-based content. One of the causes that discourage access to digital information is culture and language differences. Efforts should be made to make ICTs available in local languages if they are to be demystified, adopted and utilized by locals.

In general, ICT goals in Africa are: to establish an environment that encourages networking of services and applications; promoting e-commerce and trade promotion programmes for goods and services; promoting internet access to exchange and access digital content; establishing egovernment; promoting education and on-line services; strengthening network security; building and developing e-society and ICT human resources. 


\section{References}

[1].Adamali, A. Coffey, J. O., \& Safdar, Z (2006) Trends in national e-strategies: A review of 40 countries. In the World Bank Information and Communication for development: Global trends and policies. Washington DC: The World Bank.

[2].Al-Jayyousi, R.O (2017) Integral Innovation: New Worldviews, London, United Kingdom published by Taylor \& Francis Ltd https://siteresources.worldbank.org/UNICATIONANDTECHNOLOGIES/Resources/IC4D-2012-Report.pdf.

[3].Africa Economic outlook (2012) promoting youth employment available online http://www.cpahq.org/cpahq/cpadocs/Promoting\%20Youth\%20Employment.pdf accessed 29/08/17.

[4].Africa Development Bank (2016) Jobs for Youth in Africa Strategy for Creating 25 Million Jobs and Equipping 50 Million Youth 2016-2025 available online https://www.afdb.org/fileadmin/uploads/afdb/Documents/BoardsDocuments/Bank_Group_Strategy_for_Jobs_for_Youth_in_Africa_2016-2025_Rev_2.pdf.

[5].Andrianaiv, M and Kpodar, K (2011) IMF Working Paper: ICT, Financial Inclusion, and Growth: Evidence from African Countries available online

http://ww.w.gsmworld.com/mobilefordevelopment/wp-

content/uploads/2012/06/imfworkingpaperictfinancialinclusion.pdf accessed 29/08/17.

[6].Beck, T et al (2007) - Reaching Out: Access to and Use of Banking Services Across Countries, Journal of Financial Economics, 85(1), pp. 234-66.

[7].Boriana, Y. 2015. Financial Inclusion in the ECCAS region: where do we stand? ECCAS Regional Conference, Brazzaville, Congo March 23, 2015.

[8].Beder, Sharon, (1994). The role of technology in sustainable development, Technology and Society, Vol. 13, no. 4, winter, pp. 14-19.

[9].Beder, S, The Role of Technology in Sustainable Development, Herkert, JR (ed), Social, Ethical, and Policy Implications of Engineering, Selected Readings, IEEE, 2000, 230-235. Copyright IEEE.

[10]. Baro, E (2011) A Critical Examination of Information and Communication Technology Policies: Effects on Library Services in Nigeria available online http://www.webpages.uidaho.edu/ mbolin/baro.htm.

[11]. Curtain, R(2015) Promoting youth employment through information and communication technologies (ICT) Best practices examples in Asia and the Pacific available online http://Promoting_Youth_Employment_through_Information_and.pdf.

[12]. Chett, K (2016) Development of the Digital Economy as a driver for Economic Transformation/ Upgrading and Structural Reform available online

http://www.bricsresearch.org.za/dynamic/uploads/documents/KrishChetty-

DevelopmentDigitalEconomyDriverEconomicTransformation.pdf accessed 10/09 /17.

[13]. Crede, A., \& Mansell, R. (1998). "Knowledge societies in a nutshell: Information technologies for sustainable development". Ottawa, Canada: IDRC.

[14]. Consultative Group to Assist the Poor, 2009, Financial Access 2009-Measuring Access to Financial Services around the World, Technical Report (Washington: CGAP).

[15]. Donner, Jonathan, 2008, - Research Approaches to Mobile Use in the Developing World: A Review of the Literature, The Information Society, 24(3), pp. 140-59.

[16]. Farid, S (2015) The Role of Technology in the Sustainable Economic Development- the Case of Africa Journal of Economic Research, 1(1).1-11 available online

http://manuscript.advancejournals.org/uploads/c1e0e12f4e370069375a227f01237093466e4f20ff57b66aaec6e8f0889 be565/Manuscript/354.pdf accessed 15/08/17.

[17]. Global Internet Report (2014) Open and Sustainable Access for All available online https://www.internetsociety.org/sites/default/files/Global_Internet_Report_2014_0.pdf accessed 20/08/17.

[18]. HAFIZ et al (2013) An Exploratory Evidence of Youth's ICT empowerment in Nigeria

http://pakacademicsearch.com/pdf-files/ech/517/17-25\%20Vol\%205,\%20No\%2010\%20(2013).pdf $\quad$ accessed $31 / 08 / 17$. 
DOI: $10.21522 / \mathrm{TIJAR} .2014 .04 .02 . A r t 008$

ISSN: $2520-3088$

[19]. Helmore et al (2009) MICROFINANCE IN AFRICA STATE-OF-THE-SECTOR REPORT BRINGING FINANCIAL SERVICES TO AFRICA'S POOR available online https://care.ca/sites/default/files/files/publications/accessafricasosreport.pdf accessed 31/08/17.

[20]. Hoffman, K., \& Girvan, N. (1990). Managing International Technology Transfer: A Strategic Approach for Developing, IDRC.

[21]. ICT and SDGS Final Report (Undated) How Information and Communications Technology can Accelerate Action on the Sustainable Development Goals available online https://www.ericsson.com/assets/local/news/2016/05/ict-sdg.pdf accessed 17/08/17.

[22]. ILO (2001): World Employment Report 2001: Life at Work in the Information Economy, Geneva, p. 52.

[23]. ITU Report (undated) How Information and Communications Technology can Accelerate Action on the Sustainable Development Goals available online https://www.ericsson.com/assets/local/news/2016/05/ict-sdg.pdf accessed 18/08/17.

[24]. Ling, R. (2000). The Impact of Mobile Phones on four Established Social Institutions. Paper presented at the International Society for the study of European Ideas conference, Bergen, Norway.

[25]. Radosevic, S. (1999). International Technology Transfer and Catch-up in Economic Development. Nothampton, MA: Edward Edgar Publishing.

[26]. Rogers, E. M. (1962). Diffusion of Innovations. New York: The Free Press of Glencoe.

[27]. Sach, D (2014) Sustainable Development Goals for a New Era available online http://earth.columbia.edu/sitefiles/file/Sachs\%20Writing/2014/HORIZONS_Sustainable\%20Development\%20Goals $\% 20$ for\%20a\%20New\%20Era_2014.pdf accessed 24/08/17.

[28]. Sofowora, O (2009) The potential of using information and communication technology for poverty alleviation and economic empowerment in Osun State, Nigeria published international Journal of Education and Development using Information and Communication Technology (IJEDICT), 2009, Vol. 5, Issue 3, pp. 131-140

[29]. Sofowora, O (2009) The potential of using information and communication technology for poverty alleviation and economic empowerment in Osun State, Nigeria published in International Journal of Education and Development using Information and Communication Technology (IJEDICT), 2009, Vol. 5, Issue 3, pp. 131-140

[30]. Sesan, G (2004). ADF Youth Speak on Employment as a Response to UN youth Employment Network. Published by the Intentional Institute for Commutation and Development (IICD), Raamweg5 2502 Hague, Netherlands. http://rs6.Net/tn.jsp/et.

[31]. Sreedevi, V (2011) ICT for Financial Inclusion published INTERNATIONAL JOURNAL OF BUSINESS MANAGEMENT, ECONOMICS AND INFORMATION TECHNOLOGY Vol. 3, No. 2, July-December 2011: 331-334 available online http://serialsjournals.com/serialjournalmanager/pdf/1330077211.pdf accessed 31/08/17

[32]. Mariscal, J et al. (undated) Employment and Youth Inclusion into the Labor Force via Training in Information and Communication Technologies (ICTs): The Cases of Brazil, Colombia, and Mexico available online http://itidjournal.org/itid/article/viewFile/358/159 accessed 01/09/17.

[33]. Michael, O and Samson, A (2014) The Impact of Information and Communication Technology on Youth and its Vocational Opportunities in Nigeria published Journal of Good Governance and Sustainable Development in Africa, Vol. 2, No 1, Jan., 2014 Website: http://www.rcmss.com ISSN: 2346-724X (Print) ISSN: 2354-158X (Online) Oladunjoye Idowu Michael \& Audu Joel Samson, 2014, 2(1):106-112 available online accessed 01/09/17

[34]. Mimbi, L and Bankole, F (2015) ICT and Health System Performance in Africa: A MultiMethod Approach available

online https://www.researchgate.net/profile/Felix_Olu_Bankole/publication/285589431_ICT_and_Health_System_Perform ance_in_Africa_A_Multi-_Method_Approach/links/566091c008aebae678aa22b6/ICT-and-Health-System-

Performance-in-Africa-A-Multi-Method-Approach.pdf accessed 29/08/17.

[35]. Prahalad, C.K. (2000): "Let's focus on the digital dividend: Conventional mental models may be an impediment to the diffusion of internet benefits to poorer countries", in European Business Forum, (http://www.ebfonline.com/at_forum/at_forum.asp?linked=32\&id=26).

[36]. UN DESA (2008) Innovation for Sustainable Development: Local Case Study from Africa available online https://sustainabledevelopment.un.org/content/documents/publication.pdf accessed 26/07/17. 
[37]. UN DESA (2008), Trends in Sustainable Development: Africa Report, 2008/2009; Convention on Biodiversity (200), Global Biodiversity Outlook 2, http://www.cbd.int/doc/gbo2/cbd-gbo2-en.pdf.

[38]. OECD (2012) Innovation for Development: A discussion of the issues and an overview of work of the OECD Directorate for Science, Technology and Industry available online http://www.oecd.org/innovation/inno/50586251.pdf accessed on 15/08/2017.

[39]. UNDP (2003) "The Role of ICT in Enhancing the Achievement of Millennium Development Goals," A Contribution to the Work of Millennium Project Task Force 10 on Science and Technology (February 21, 2003) CIDA matrix.

[40]. U.S. Congress, Office of Technology Assessment, Perspectives on the Role of Science and Technology in Sustainable Development, OTA-ENV-609 (Washington, DC: U.S. Government Printing Office, September 1994) available online http://ota.fas.org/reports/9422.pdf accessed 15/08/17.

[41]. United Nations ICT Task Force (2003) Tools for Development: Using Information and Communications Technology to Achieve the Millennium Development Goals available online https://www.itu.int/net/wsis/stocktaking/docs/activities/1103056110/ICTMDGFinal.pdf accessed 16/08/2017

[42]. United Nations Development Programme (2001). Human Development Report. Making New Technologies Work for Human Development. Published for UNDP Oxford University press, New York.

[43]. UNDP (2001): Human Development Report 2001: Making new technologies work for human development, published for UNDP, Oxford University Press, New York, pp. 39 \& 45.

[44]. Ukommi, A and Okeagu, B (2015) Information and Communication Technology (ICT) Education and Youth Entrepreneurship in Uyo, Akwa Ibom State of Nigeria published IOSR Journal Of Humanities And Social Science (IOSR-JHSS) Volume 20, Issue 7, Ver. IV (July 2015), PP 01-14 available online

http://www.iosrjournals.org/iosr-jhss/papers/Vol20-issue7/Version-4/A020740114.pdf.

[45]. World Bank (2007). Development Indicators Data Bank. Washington D.C. Dol.gov/asp/.../report/chartbook/2007-01/appendix a-populationhtml. 